\title{
Synthesis, Characterization and Analytical Application of Antimony (III) Iodovanadate
}

\author{
Subhash Chand*,Vijayata, Rekha, Brajesh Pal \\ Chemistry Department Meerut College, Meerut
}

\begin{abstract}
Antimony (iii)iodovanadate has been synthesized under varying ratio of antimony trichloride, sodium metavanadate and potassium iodate solutions. The synthesized material shows ion exchange capacity $2.67 \mathrm{meq} / \mathrm{g}$ for $\mathrm{Na}^{+}$ions. The material has been characterized on the bases of IR, XRD and TGA. The chemical stability of the material has been determined in acid and base solutions of different concentration. Thermal stability of this exchanger has also been determined. Distribution studies exhibit maximum $\mathrm{Kd}$ value for $\mathrm{Ni}^{++}$and minimum for $\mathrm{Pb}^{++}$. The utility of the exchanger is revealed from the binary seperations. The exchanger has been employed to achieve Binary seperations $\mathrm{Ni}-\mathrm{Zn}, \mathrm{Ni}-\mathrm{Pb}, \mathrm{Pb}-\mathrm{Zn}$ and $\mathrm{Pb}-\mathrm{Mg}$ pairs.
\end{abstract}

Keywords: Inorganic cation exchanger, Ion exchange capacity, Chemical stability, Thermal stability, Distribution coefficient, Biary Seperation.

\section{Introduction}

The importance of synthetic inorganic ion exchangers has increased attention due to their high selectivity and stability at elevated temperatures 1 . In recent years several theories for ion exchange equilibria have developed and tried on inorganic ion exchange materials ${ }^{2}$. Ion exchange is a widely used technique for selective separation of ions from different solutions. A highly selective ion exchange process is required for the treatment of waste effluent as, in most cases, the toxic ion to be removed, exists at very low concentration together with other ions that exist at much higher concentration ${ }^{3}$. Analytical application in the field of sepaation science have been reviewed by Inczedy ${ }^{4}$ and Walton ${ }^{5}$. Antimonates of zirconium ${ }^{6}$, titanium ${ }^{7}, \operatorname{tin}^{8}, \operatorname{cerium}^{9}$, theorium $^{10}$, tantalum $^{11}$ and antimony(III) tungstosilicate ${ }^{12}$ have been synthesized and used for various separation in analytical chemistry.

The present work deals with the synthesis and ion exchange properties of antimony(III) iodovanadate. The material has been characterized on the basis of thermal studies, chemical stability, TGA, XRD, IR and distribution studies. The exchanger is found to be selective for $\mathrm{Ni}^{++}$and $\mathrm{Pb}^{++}$as per distribution studies done in the research laboratory. Antimony(III) based ion exchanger received attention because of their excellent ion exchange behavior. The reproducible behavior and ion exchange properties prove their significances. Their utility has been demonstrated for the binary separations of various metal ions. Antimony(III) iodovanadate has been used for binary seperations of the following pairs: $\mathrm{Ni}^{2+}-\mathrm{Cd}^{2+}, \mathrm{Pb}^{2+}-$ $\mathrm{Zn}^{2+} \mathrm{Ni}^{2+}-\mathrm{Pb}^{2+}$ and $\mathrm{Ni}^{2+}-\mathrm{Zn}^{2+}$. The exchanger was also used for the removal of metal ions from aqueous media. Qualitative analysis of certain metal ions solutions before passing through the exchanger and after passing through the exchanger was done the ensure the presence and absence of metal ions in aqueous solutions respectively.

\section{Experimental}

Regents \&Chemicals - Antimony tri chloride, sodium meta vanadate and potassium iodate (All CDH of AR grade) were used. All other reagents used were also of analytical or chemically pure grade.

Instrumentation - Oven NSW (INDIA) (model - I 43), ROTARY SHAKER TANCO, Magnetic stirrer with hotplate, MUFFL FURNACE (Digital temp centroller) SHIVAKI T-701 and Toshniwal research $\mathrm{p}^{\mathrm{H}}$ meter model $\mathrm{p}^{\mathrm{H}} 110$, Samson electronic weighing balance (Model - $\left.300 \mathrm{D}\right)$ were also used in the Research laboratory, chemistry department, Meerut College Meerut. TGA, XRD and IR were obtained from IIT Roorkee where Perkin Elmer (Pyris Diamond) in alumina pan with a current of nitrogen, Thermo Nicolet for TGA, Philips Analytical X-ray B.V. diffectrometer for XRD and Thermo Nicolet IR-spectrophotometer for IR were available. Synthesis

Six samples of Antimony(III)iodovanadate were prepared by mixing $0.05 \mathrm{M}$ Antimony trichloride, $0.1 \mathrm{M}$ Potassium iodate and $0.1 \mathrm{M}$ Sodium metavanadate solutions in different volume ratios with continuous stirring. The $\mathrm{pH}$ was adjusted to 1 of all the six mixtures. The formed precipitates were allowed to settle over 
night and then filtered and washed with distilled water. The precipitates of all the six ratios were dried in an oven at $40+1^{0} \mathrm{C}$. The dried materials were broken down into granules by placing them in distilled water just after removing them from the oven and finally converted to the acid form by immersing them in molar nitric acid solution which was intermittently replaced, washed with distilled water till the materials become free of acid and again dried at room temperature to make ready for characterization. Six yellow coloured Antimony (III)iodovanadate samples were obtained. The results are summarized in Table 1.

\section{Determination of Ion Exchange Capacity}

Ion exchange capacity (IEC) of all the six sample were determined by column method (Table 1). On the basis of IEC sample No. AIV 6 was selected for detailed study and therefore was synthesized in bulk by the procedure as adopted earlier. $\mathrm{p}^{\mathrm{H}}$ titration method was also followed for the determination of IEC of the exchanger synthesized in bulk.

Column Method: - The ion exchange capacity of the selected sample was also determined for different metal ions by column method. $0.05 \mathrm{~g}$ of Antimony (III)iodovanadate in the $\mathrm{H}^{+}$form was packed in a glass column having a glass wool support at the base. A $0.1 \mathrm{M}$ solution of different metal ions were passed through the bed of ion exchanger slowly by adjusting the effluent rate at 9-10 drops per minute. The collected effluents were titrated against a standard sodium hydroxides solution/ Ethylediamine tetraacitic acid solution using appropriate indicators. The result is summarized in Table 2.

$\mathbf{p}^{\mathbf{H}}$ Titration Method :- $\mathrm{pH}$ titration was also performed by batch method. Equal portions of the exchanger were equilibrated with different volume mixture of $0.1 \mathrm{M} \mathrm{NaCl}$ and $0.1 \mathrm{M} \mathrm{NaOH}$ solutions. The graph was plotted between $\mathrm{pH}$ and hydozylion concentration (Fig1).

\section{Thermal Studies}

Ten equal portions of Antimony(III)iodovanadate were heated at different temperatures in muffle furnace for $1 \mathrm{hr}$ and then the ion exchange capacity was determined of all the samples using a standard sodium hydroxide solution. The results are summarized in Table 3. The graph was plotted between temperature and I.E.C. (Fig 2). TGA of the exchanger shows the loss of water molecules and other components at different temperatures. Finally the weight of the material become constant (Fig. 3).

\section{Chemical Stability}

Equal amounts of the exchanger were kept in equal volumes of the various mineral acid solutions, base solutions and salt solutions of different concentrations for $24 \mathrm{hrs}$ with intermittent shaking. The results are summarized in Table 4.

\section{Distribution Studies}

Distribution studies were carried out for several metal ions by batch process [9]. Seven equal portions of the exchanger in the $\mathrm{H}^{+}$from were equilibrated with equal volumes of solutions of different metal salts in aqueous medium. The metal ion concentrations in the solution before and after equilibrium were determined by titrating against EDTA solution. The distribution coefficient values were calculated using the following formula.

$$
\mathrm{Kd}=\frac{I-F}{F} \times \frac{V}{W}(m l / g)
$$

Where

$$
\begin{array}{lll}
\mathrm{Kd} & = & \text { Distribution Coefficient } \\
\mathrm{I} & = & \text { Initial amount of the ion in the solution phase. } \\
\mathrm{F} & = & \text { Final amount of the ion in the Solution phase. } \\
\mathrm{V} & = & \text { Volume of the solution }(\mathrm{ml}) \\
\mathrm{W} & = & \text { Weight of the ion exchanger }(\mathrm{g}) .
\end{array}
$$

\section{Applications Binary Seperation Of Metal Ions}

Important quantative seperations of metal ions were performed using column containing $200 \mathrm{mg}$ of the material. The column was washed with demineralized water and the mixture to be separated was loaded on it in solution form. Recycling was done 3 times to ensure complete adsorption of the cations on the column bed. The metal ions were eluted at a flow rate of 3 drops $\min ^{-1}$ using appropriate eluents. The pairs were selected on the basis of Kd values obtained. The metal ions in the effluent were determined quantatively by EDTA titration using suitable indicator (Table. 6) 


\section{Result And Discussion}

The properties of inorganic ion exchanger very widely changed when the conditions of their preparation are changed [10]. Six different samples of Antimony(III) iodovanadate have been prepared under varying ratios (Table 1). The synthesized Antimony(III) iodovanadate exhibits good ion exchange capacity (Table 2).Antimony(III) iodovanadate shows the maximum ion exchange capacity for $\mathrm{Na}^{+}$ion is found to be $2.67 \mathrm{meq} / \mathrm{g}$. The sequence of ion which exchange capacity for the alkali and alkaline earth metal ions as shown by the ion exchanger by column method is as given below (Table 2).

$$
\begin{gathered}
\mathrm{Na}^{+}>\mathrm{K}^{+} \\
\mathrm{Ba}^{2+}>\mathrm{Ca}^{2+}>\mathrm{Mg}^{2+}
\end{gathered}
$$

The study including the effect of temperature on ion exchange capacity of Antimony (III) iodovanadate shows that the ion exchange capacity decreases with increase in temperature.

The exchanger is found to be stable in water. Partly dissolved in

$2 \mathrm{MH}_{2} \mathrm{SO}_{4}, 2 \mathrm{MNaOH}, 2 \mathrm{MNH}_{4} \mathrm{Cl}, 4 \mathrm{M} \mathrm{H}_{2} \mathrm{SO}_{4}, 4 \mathrm{MHNO}_{3}$. Complete dissolve in $4 \mathrm{M} \mathrm{HCl}$ solutions.

The distribution study of the exchanger for seven metal ions shows the affinity in the following order:

$$
\mathrm{Ni}^{2+}>\mathrm{Mg}^{2+}>\mathrm{Mn}^{2+}>\mathrm{Co}^{2+}>\mathrm{Cd}^{2+}>\mathrm{Pb}^{2+}>\mathrm{Zn}^{2+}
$$

This shows that the exchanger is selective for nickel ions.

X-ray powder diffraction pattern shows the exchanger to be crystalline in nature, (fig.4). $4 \mathrm{M} \mathrm{HNO}_{3}$ and Completely dissolved in $4 \mathrm{M} \mathrm{HCl}$ solutions.

The distribution study of the exchanger for seven metal ions shows the affinity in the following order:

$$
\mathrm{Ni}^{2+}>\mathrm{Mg}^{2+}>\mathrm{Mn}^{2+}>\mathrm{Co}^{2+}>\mathrm{Cd}^{2+}>\mathrm{Pb}^{2+}>\mathrm{Zn}^{2+}
$$

This shows that the exchanger is selective for nickel ions.

IR of the exchanger is given in fig. 2.6. Peaks are at $3433 \mathrm{~cm}^{-1}$ for water molecules, $2450.65 \mathrm{~cm}^{-1}$ for metaloxide, $1633.30 \mathrm{~cm}^{-1}$ for H-O-H bonding, $756.96 \mathrm{~cm}^{-1}$ for iodate, 450.22 for vanadium oxide. The presence of water molecules is well evident from the figure 5 .

The present study shows that the exchanger is suitable for the binary separation of $\mathrm{Ni}^{2+}-\mathrm{Zn}^{2+}, \mathrm{Ni}^{2+}$. $\mathrm{Cd}^{2+}, \mathrm{Pb}^{2+}-\mathrm{Zn}^{2+}$ and $\mathrm{Ni}^{2+}-\mathrm{Pb}^{2+}$ metal ion pairs. The result are shown. (Table 6.)

\section{Conclusion}

The present study clearly indicates that the synthesized exchanger can be used successfully in acid solutions of 0.05 Molar strength. The study also shows the selectivity of the exchanger towords nickel ions.

\section{Acknowledgment}

\begin{tabular}{|c|c|c|c|c|c|c|c|c|c|c|}
\hline \multirow[t]{2}{*}{$\begin{array}{l}\text { S. } \\
\text { No. }\end{array}$} & \multicolumn{3}{|c|}{ Molar Conce } & \multicolumn{3}{|c|}{$\begin{array}{l}\text { Mixing } \\
\text { Ratio }\end{array}$} & \multirow[t]{2}{*}{$\begin{array}{l}\text { pH of the } \\
\text { mixture }\end{array}$} & \multirow[t]{2}{*}{$\begin{array}{l}\text { Appearance of } \\
\text { the precipitate }\end{array}$} & \multirow{2}{*}{$\begin{array}{c}\text { Appearance of } \\
\text { beads after drying } \\
\text { at } 40+1^{\circ} \mathrm{C}\end{array}$} & \multirow{2}{*}{$\begin{array}{c}\text { I.E.C. for } \\
\mathrm{Na}^{+}\left(\mathbf{m e q}_{1} \mathrm{gm}^{-}\right.\end{array}$} \\
\hline & $\mathbf{A}$ & I & $\mathbf{v}$ & $\mathbf{A}$ & $\mathbf{I}$ & $\mathbf{V}$ & & & & \\
\hline 1 & $0.05 \mathrm{M}$ & $0.1 \mathrm{M}$ & $0.1 \mathrm{M}$ & 1 & 1 & 1 & 1 & Lemon yellow & Lemon yellow & $*$ \\
\hline 2 & $0.05 \mathrm{M}$ & $0.1 \mathrm{M}$ & $0.1 \mathrm{M}$ & 1 & 2 & 2 & 1 & Lemon yellow & Lemon yellow & $*$ \\
\hline 3 & $0.05 \mathrm{M}$ & $0.1 \mathrm{M}$ & $0.1 \mathrm{M}$ & 2 & 1 & 1 & 1 & Lemon yellow & Lemon yellow & 1.2 \\
\hline 4 & $0.05 \mathrm{M}$ & $0.1 \mathrm{M}$ & $0.1 \mathrm{M}$ & 2 & 2 & 1 & 1 & Lemon yellow & Lemon yellow & 1.6 \\
\hline 5 & $0.05 \mathrm{M}$ & $0.1 \mathrm{M}$ & $0.1 \mathrm{M}$ & 3 & 1 & 1 & 1 & Lemon yellow & Lemon yellow & 1.28 \\
\hline 6 & $0.05 \mathrm{M}$ & $0.1 \mathrm{M}$ & $0.1 \mathrm{M}$ & 3 & 2 & 2 & 1 & Lemon yellow & Lemon yellow & 2.67 \\
\hline
\end{tabular}
facilities.

We are thankful to Head of chemistry Departments IIT, Roorkee (U.K.) for providing us necessary

TABLE-1SYNTHESIS OF ANTIMONY(III) IODOVANADATE

A - Antimony trichloride Solution

I- Potassium iodate

$\mathrm{V}$ - Sodium metavanadate Solution 
Synthesis, Characterization And Analytical Application Of Antimony (Iii) Iodovanadate

TABLE - 2I.E.C OF ANTIMONY(III) IODOVANADATE FOR DIFFERENT METAL IONS

\begin{tabular}{|c|c|c|}
\hline SL.No. & Cation & I.E.C. $\left(\mathbf{m e q} \mathbf{g m}^{-\mathbf{1}}\right)$ \\
\hline $\mathbf{1}$ & $\mathrm{Na}^{+}$ & 2.28 \\
\hline $\mathbf{2}$ & $\mathrm{K}^{+}$ & 1.7 \\
\hline $\mathbf{3}$ & $\mathrm{Mg}^{++}$ & 1.16 \\
\hline $\mathbf{4}$ & $\mathrm{Ca}^{++}$ & 2.4 \\
\hline $\mathbf{5}$ & $\mathrm{Ba}^{++}$ & 2.6 \\
\hline
\end{tabular}

Alkali earth metal ions $-\mathrm{Na}^{+}>\mathrm{K}^{+}$

Alkaline earth metal ions $-\mathrm{Ba}^{++}>\mathrm{Ca}^{++}>\mathrm{Mg}^{++}$

TABLE - 3THERMAL STABILITY OF ANTIMONY(III) IODOVANADATE

\begin{tabular}{|c|c|c|c|c|c|c|}
\hline SI.No. & $\begin{array}{c}\text { Temperature } \\
\left({ }^{\circ} \mathbf{C}\right)\end{array}$ & $\begin{array}{c}\text { wt. before } \\
\text { heating }(\mathbf{g})\end{array}$ & $\begin{array}{c}\text { wt. after } \\
\text { heating (g) }\end{array}$ & Loss in wt. (g) & $\begin{array}{c}\text { Colour after } \\
\text { heating }\end{array}$ & $\begin{array}{c}\text { I.E.C. }\left(\mathbf{m e q}_{\mathbf{g m}} \mathbf{- 1}\right) \\
\text { after heating }\end{array}$ \\
\hline $\mathbf{1}$ & $50^{\circ} \mathrm{C}$ & 0.50 & 0.50 & No Effect & Yellow & 2.67 \\
\hline $\mathbf{2}$ & $100^{\circ} \mathrm{C}$ & 0.50 & 0.49 & 0.01 & Yellow & 2.55 \\
\hline $\mathbf{3}$ & $150^{\circ} \mathrm{C}$ & 0.50 & 0.48 & 0.02 & Yellow & 2.50 \\
\hline $\mathbf{4}$ & $200^{\circ} \mathrm{C}$ & 0.50 & 0.47 & 0.03 & Yellow & 2.40 \\
\hline $\mathbf{5}$ & $250^{\circ} \mathrm{C}$ & 0.50 & 0.46 & 0.04 & Yellow & 2.35 \\
\hline $\mathbf{6}$ & $300^{\circ} \mathrm{C}$ & 0.50 & 0.45 & 0.05 & Yellow & 1.89 \\
\hline $\mathbf{7}$ & $350^{\circ} \mathrm{C}$ & 0.50 & 0.44 & 0.06 & Yellow & 1.82 \\
\hline $\mathbf{8}$ & $400^{\circ} \mathrm{C}$ & 0.50 & 0.43 & 0.07 & Yellow & 1.77 \\
\hline $\mathbf{9}$ & $450^{\circ} \mathrm{C}$ & 0.50 & 0.42 & 0.08 & Brown & 1.17 \\
\hline $\mathbf{1 0}$ & $500^{\circ} \mathrm{C}$ & 0.50 & 0.41 & 0.09 & Brown & 0.80 \\
\hline
\end{tabular}

TABLE - 4CHEMICAL STABILITY OF ANTIMONY(III) IODOVANADATE

\begin{tabular}{|c|c|c|c|c|c|c|}
\hline \multirow[t]{2}{*}{ SL.No. } & \multirow[t]{2}{*}{ Solution } & \multicolumn{4}{|c|}{ Effect of Solution on BIT } & \multirow{2}{*}{$\begin{array}{l}\mathrm{W}_{1}=\text { weight of IE before } \\
\text { treating with solution }\end{array}$} \\
\hline & & $\mathbf{W}_{1}$ & $\mathbf{W}_{2}$ & Inference & Colour & \\
\hline 1 & $2 \mathrm{M} \mathrm{H}_{2} \mathrm{SO}_{4}$ & 0.25 & 0.24 & PD & Yellow & \multirow{6}{*}{$\begin{array}{l}\mathrm{W}_{2}=\text { weight of IE after } \\
\text { treating with solution } \\
\mathrm{PD}=\text { Partly dissolved } \\
\mathrm{IE}=\text { Ion Exchanger } \\
\text { ATS=Antimony(III)iodo } \\
\text { vanadate } \\
\mathrm{CD}=\text { Complete } \\
\text { Dissolve }\end{array}$} \\
\hline 2 & $4 \mathrm{M} \mathrm{H}_{2} \mathrm{SO}_{4}$ & 0.25 & 0.23 & $\mathrm{PD}$ & Yellow & \\
\hline 3 & $4 \mathrm{M} \mathrm{HNO}_{3}$ & 0.25 & 0.20 & PD & $\begin{array}{l}\text { Golden } \\
\text { Yellow }\end{array}$ & \\
\hline 4 & $4 \mathrm{M} \mathrm{HCl}$ & 0.25 & $\mathrm{CD}$ & $\mathrm{CD}$ & Yellow & \\
\hline 5 & $2 \mathrm{M} \mathrm{NaOH}$ & 0.25 & 0.10 & PD & Yellow & \\
\hline 6 & $2 \mathrm{M} \mathrm{NH}_{4} \mathrm{Cl}$ & 0.25 & 0.23 & PD & Yellow & \\
\hline
\end{tabular}

TABLE - 5DISTRIBUTION STUDIES OF ANTIMONY(III) IODOVANADATE

\begin{tabular}{|c|c|c|c|}
\hline SL.No. & Cation & Taken as & Kd (ml/g) \\
\hline $\mathbf{1}$ & $\mathrm{Mg}^{2+}$ & Chloride & 40.52 \\
\hline $\mathbf{2}$ & $\mathrm{Zn}^{2+}$ & Sulphate & 18.4 \\
\hline $\mathbf{3}$ & $\mathrm{Cd}^{2+}$ & Nitrate & 16.44 \\
\hline $\mathbf{4}$ & $\mathrm{Pb}^{2+}$ & Nitrate & 111.25 \\
\hline $\mathbf{5}$ & $\mathrm{Ni}^{2+}$ & Sulphate & 33.12 \\
\hline $\mathbf{6}$ & $\mathrm{Co}^{2+}$ & Sulphate & 85.55 \\
\hline $\mathbf{7}$ & $\mathrm{Mn}^{2+}$ & Sulphate & \\
\hline
\end{tabular}


TABLE-6BINARY SEPERATION

\begin{tabular}{|c|c|c|c|c|c|c|c|c|}
\hline Sl. No. & $\begin{array}{l}\text { Sample } \\
\text { No. }\end{array}$ & $\begin{array}{l}\text { Sepa- } \\
\text { ration }\end{array}$ & $\begin{array}{l}\text { Amount } \\
\text { Loaded }(\mu \mathrm{g})\end{array}$ & $\begin{array}{l}\text { Amount } \\
\text { Founed } \\
(\mu g)\end{array}$ & $\begin{array}{l}\text { \% of } \\
\text { Metal } \\
\text { Ion } \\
\text { Eluted }\end{array}$ & $\begin{array}{l}\text { \% } \\
\text { Error }\end{array}$ & $\begin{array}{l}\text { Total } \\
\text { elution } \\
\text { volum } \\
\text { (ml) }\end{array}$ & Eluent used \\
\hline 1. & AIV-6 & $\begin{array}{l}\mathrm{NI} \\
\mathrm{Zn}\end{array}$ & $\begin{array}{l}1545 \\
2731\end{array}$ & $\begin{array}{l}1441 \\
2875\end{array}$ & $\begin{array}{l}93.26 \\
105.27\end{array}$ & $\begin{array}{l}+6.74 \\
-5.27\end{array}$ & $\begin{array}{l}50 \\
30\end{array}$ & $\begin{array}{l}1 \mathrm{M} \mathrm{NH} 4 \mathrm{cl}+0.1 \mathrm{M} \\
\mathrm{HCl} \\
0.5 \mathrm{M} \mathrm{NH} 4 \mathrm{Cl}\end{array}$ \\
\hline 2. & AIV-6 & $\begin{array}{l}\mathrm{NI} \\
\mathrm{Cd}\end{array}$ & $\begin{array}{l}1545 \\
7238\end{array}$ & $\begin{array}{l}1572 \\
7392\end{array}$ & $\begin{array}{l}101.74 \\
102.12\end{array}$ & $\begin{array}{l}-1.74 \\
-2.12\end{array}$ & $\begin{array}{l}50 \\
50\end{array}$ & $\begin{array}{l}1 \mathrm{M} \mathrm{NH} 4 \mathrm{cl}+0.1 \mathrm{M} \\
\mathrm{HCl} \\
0.1 \mathrm{M} \mathrm{HNO}+0.5 \\
\mathrm{MNH} 4 \mathrm{OH}\end{array}$ \\
\hline 3. & AIV-6 & $\begin{array}{l}\mathrm{Pb} \\
\mathrm{Zn}\end{array}$ & $\begin{array}{l}2731 \\
990\end{array}$ & $\begin{array}{l}2731 \\
825\end{array}$ & $\begin{array}{l}83.33 \\
100.00\end{array}$ & $\begin{array}{l}16.67 \\
0.00\end{array}$ & $\begin{array}{l}40 \\
30\end{array}$ & $\begin{array}{l}1 \mathrm{M} \mathrm{NH} 4 \mathrm{cl}+0.1 \mathrm{M} \\
\mathrm{HCl} \\
0.5 \mathrm{M} \mathrm{NH} 4 \mathrm{Cl}\end{array}$ \\
\hline 4. & AIV-6 & $\begin{array}{l}\mathrm{Ni} \\
\mathrm{Pb}\end{array}$ & $\begin{array}{l}1545 \\
990\end{array}$ & $\begin{array}{l}1441 \\
1155\end{array}$ & $\begin{array}{l}93.26 \\
116.66\end{array}$ & $\begin{array}{l}+6.74 \\
-16.66\end{array}$ & $\begin{array}{l}50 \\
40\end{array}$ & $\begin{array}{l}1 \mathrm{M} \mathrm{NH} 4 \mathrm{cl}+0.1 \mathrm{M} \\
\mathrm{HCl} \\
1 \mathrm{M} \mathrm{NH} 4 \mathrm{cl}+0.1 \mathrm{M} \\
\mathrm{HCl}\end{array}$ \\
\hline
\end{tabular}

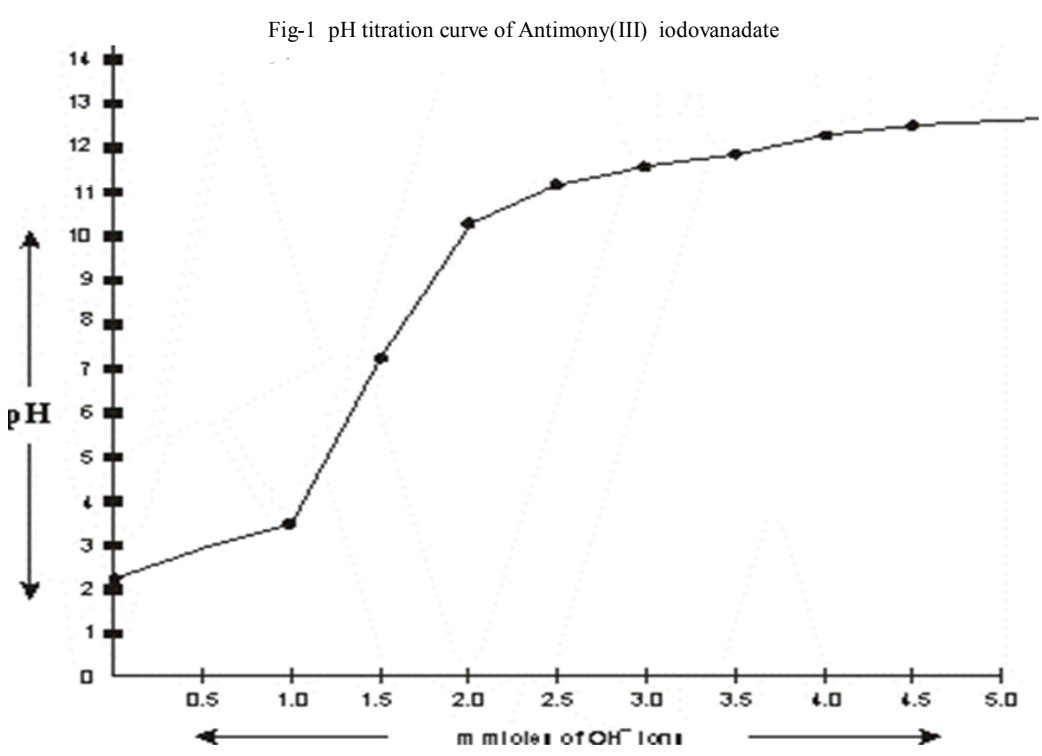

Fig-2

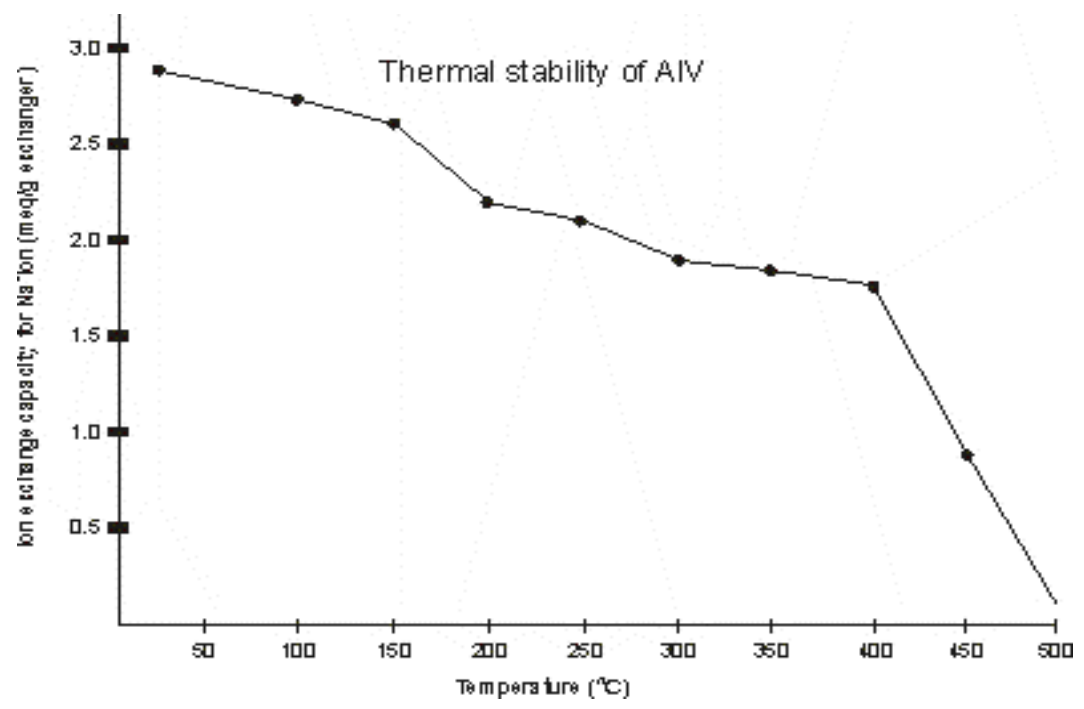

Fig: 3 TGA CURVE OF AIV 


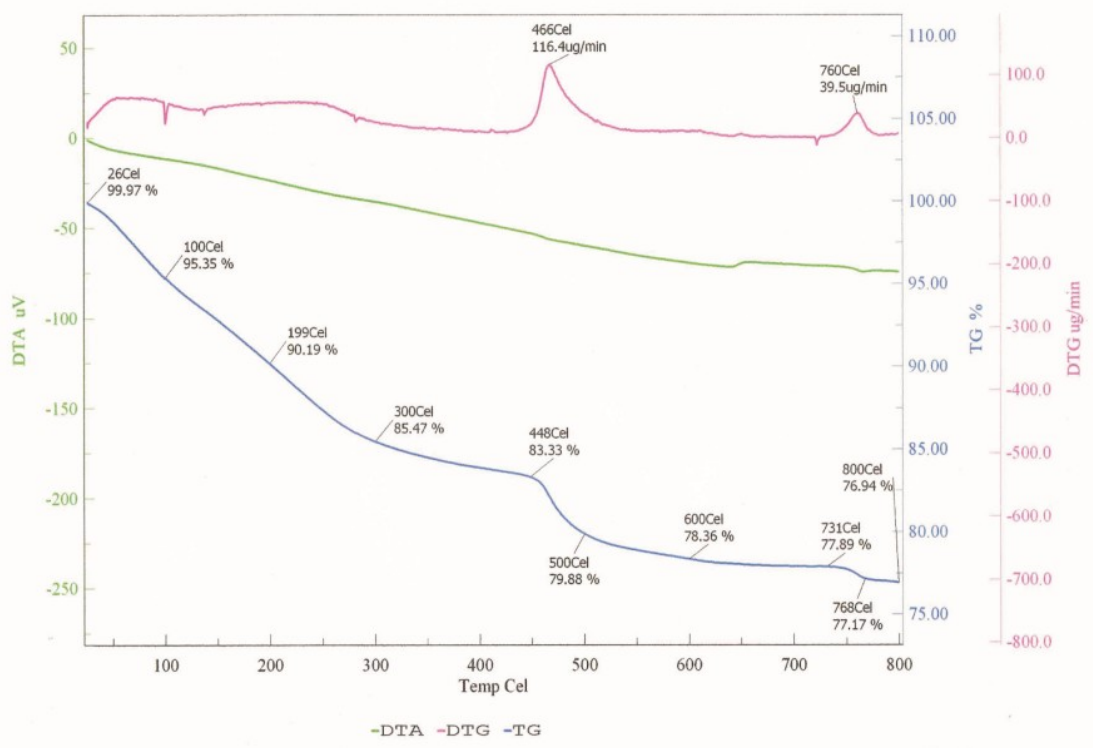

Fig: 4 IR SPECTRUM OF AIV

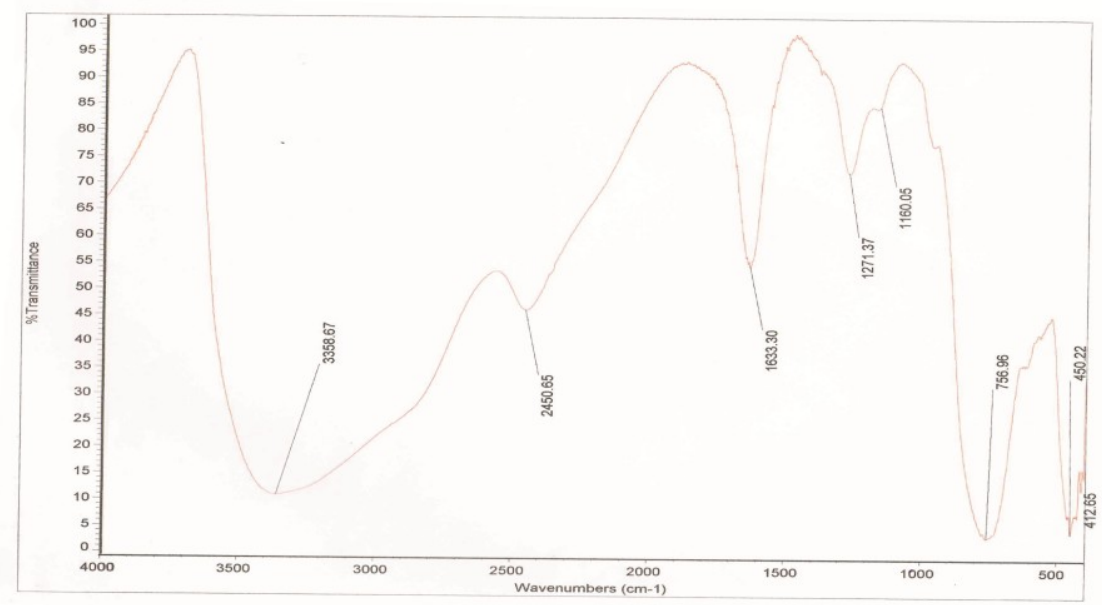

Fig:5 XRD PATTERN OF AIV

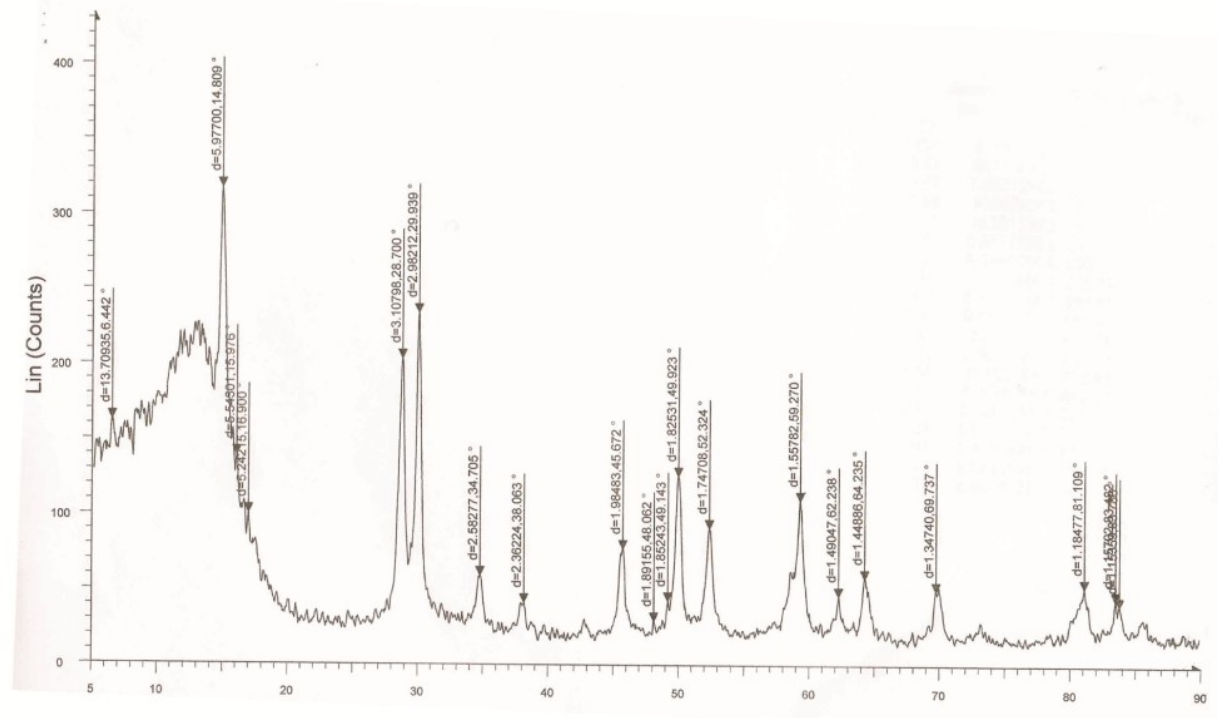




\section{References}

[1] Zakaria S. Essam, Ali M. Ismail, El- Naggar M. Ibrahim; Colloids and surface, A: Physiochemical and Engineering Aspects 210, 33-40 (2002).

[2] Nilchi A., Khanchi A., Maragheh Ghanadi M.; Talanta 56, 383 -393 (2002).

[3] Singh Premvir, Rawat J.P. \& Rahman Nafisur; Indian Journal of Chemistry, Vol. 41 A, PP. 1616-1618, Aug. (2002).

[4] Inczedy J.; Analytical applications of Ion Exchangers, Pergamon Press, Oxford, 1996.

[5] Walton H.F.; Anal. Chem. 42, 86R (1970); Ibed., 44, 256R (1972); Ibid., 46, 198R (1974); Ibid., 48, 52R (1976); Ibid., 50, 36R (1978).

[6] Phillips H.O., Kraus K.A.; J. Am. Chem. Soc., 84, 2267 (1962).

[7] Qureshi M., Kumar V.; J. Am. Chem. Soc. 84, 2267 (1962).

[8] Qureshi M., Kumar V.; Zehra, N.; J. Chrom., 67, 351 (1972).

[9] Gill J.S. Tandon S.N.; Talanta, 19, 1355 (1972).

[10] De A.K., Das S.K.; J. Indian Chem. Soc., 1063 (1976).

[11] Qureshi M., Gupta J.P., Sharma Veena; Anal. Chem., 45, 1901 (1973).

[12] Qureshi M., Varshney K.G. and Israli A.H.; J. Chromatogr, 50, 141, (1972).

[13] Manageh G.M., Husain W.S., Khanchi R.A.; Applied Radiation and Isotopes 50,459-465 (1999).

[14] Banwell Collin N., Elaine. M. Mc. Cash, Grow-Hill; Fundamentals of Molecular Splectroscopy, Fourth Edi., (1995).

[15] Nyquist A. \& Kagel R.O.; Infrared Spectra of Inorganic Compounds, Academic press, Inc. San Diego London, Boston, Vol. 4. 